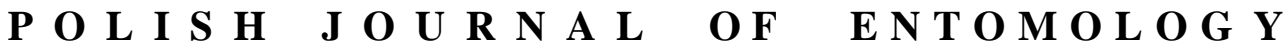

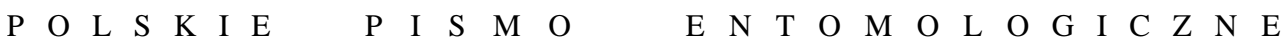

VOL. 87: 1-25

Lublin

31 March 2018

DOI: $10.2478 /$ pjen-2018-0001

\section{Systematics and faunistics of Neotropical Eucosmini, 5: Accessions}

\author{
JÓZEF RAZOWSKI $^{1 *}$, VITOR OSMAR BECKER $^{2}$ \\ ${ }^{1}$ Institute of Systematics and Experimental Zoology, Polish Academy of Sciences, Kraków, \\ 31-016 Sławkowska 17, Poland \\ ${ }^{2}$ Reserve Serra Bonita, P.O. Box 01, 45880 Camacan BA, Brazil
}

\begin{abstract}
One genus, Pollexinia gen. n. and 16 species (Quebradnotia caracae sp. n., Quebradnotia maestrae sp. n., Laculataria longiloba sp. n., Latortona figurata sp. n., Latortona percosa sp. n., Latortona guaramiranga sp. n., Gretchena argentigriseola sp. n., Rhyacionia lathrea sp. n., Crocidosema brunna sp. n., Chimoptesis ramulifera sp. n., Pelochrista crassocia sp. n., Eucosma sinus sp. n., Epiblema elensino sp. n., Epiblema ayalae sp. n., Pollexinia costaricae sp. n., Corticivora obispo sp. n.) are described. The male and female genitalia of Eucosma leucodesma MEYRICK, 1912 and the female genitalia of Pseudexentera translucens (WALSINGHAM, 1914) are also described. $P$. translucens is transferred from Eucosma and Pseudexentera dolicha RAZOWSKI \& WOJTUSIAK, 2011 to Crocidosema.
\end{abstract}

KEY WORDS: Tortricidae, Eucosmini, new genus, new species, faunistics, Neotropics.

\section{INTRODUCTION}

The present, fifth paper is the last in our series on the Neotropical Eucosmini. The preceding parts are RAZOWSKI \& BECKER (2014, 2015a, 2017a, 2017b) and one from the series (RAZOWSKI \& BECKER 2015b).

\footnotetext{
*Corresponding author: Razowski@isez.pan.krakow.pl
} 


\section{MATERIAL}

The specimens examined for this paper were collected by the second author. The types of the newly described species are temporarily housed in the BECKER collection (VOBC) and will eventually be deposited in one of the Brazilian museums. A few specimens have been kindly donated to the Institute of Systematics and Evolution of Animals, Polish Academy of Sciences, Kraków (ISEZ). The numbers cited on the labels of the specimens are the entry numbers in the register book of the VOBC.

Abbreviations used: Abbreviations used: GS - genitalia slides; NHML - Natural History Museum London (formerly the British Museum (Natural History); VOBC - Vitor Osmar BECKER Collection; WZ - Witold ZAJDA.

\section{RESULTS}

\section{Quebradnotia caracae sp. n.}

(Figs 1, 22)

\section{Diagnosis}

Q. caracae is similar and related to Q. nolckeniana (ZELLER, 1877) from Colombia and the Venezuelan $Q$. quebradae RAZOWSKI \& WOJTUSIAK, 2006 and $Q$. chasiographa RAZOWSKI $\&$ BECKER, 2006. $Q$. caracae differs from these species in that the postbasal part of the thorax is white and the hindwing is brownish grey. $Q$. caracae differs from $Q$. chasiographa in having a very large aedeagus.

\section{Description}

Wingspan $15 \mathrm{~mm}$. Head and thorax white, labial palpus grey posteriorly, tegula blackish basally. Forewing slightly expanding posteriorly; costa almost straight; termen oblique. Ground colour consisting of white fused dorsal blotches extending from wing base to before tornus and tornal blotch, and greyish remaining area strongly suffused black along white patch to middle of wing then towards apex. Costal strigulae small, greyish except for two large, apical ones; divisions blackish; ocelloid ill-defined. Cilia worn. Hindwing brownish grey, remnants of cilia paler.

Male genitalia (Fig. 1). Uncus rudimentary, represented by a pair of minute projections; socius long with triangular hairy postbasal lobe and well-sclerotized terminal part; valva broad; neck ill-defined; cucullus convex caudally with triangular dorsal lobe; sacculus convex posteriorly; aedeagus long, distinctly curved beyond zone; 15 sockets of cornuti in vesica.

Female unknown. 


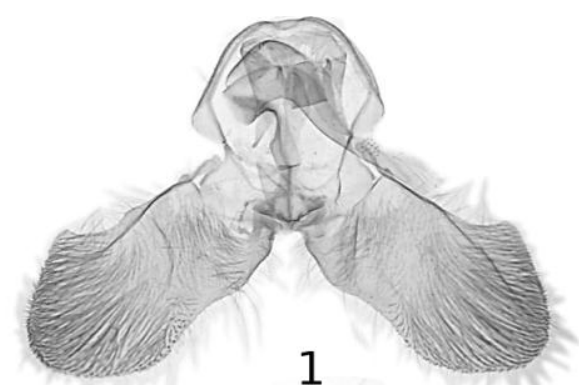

1

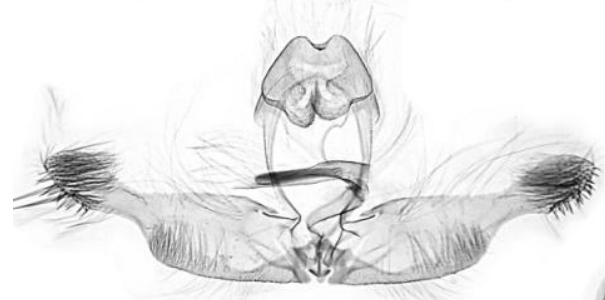

3

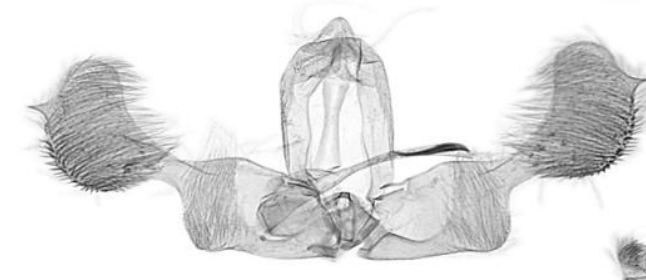

5

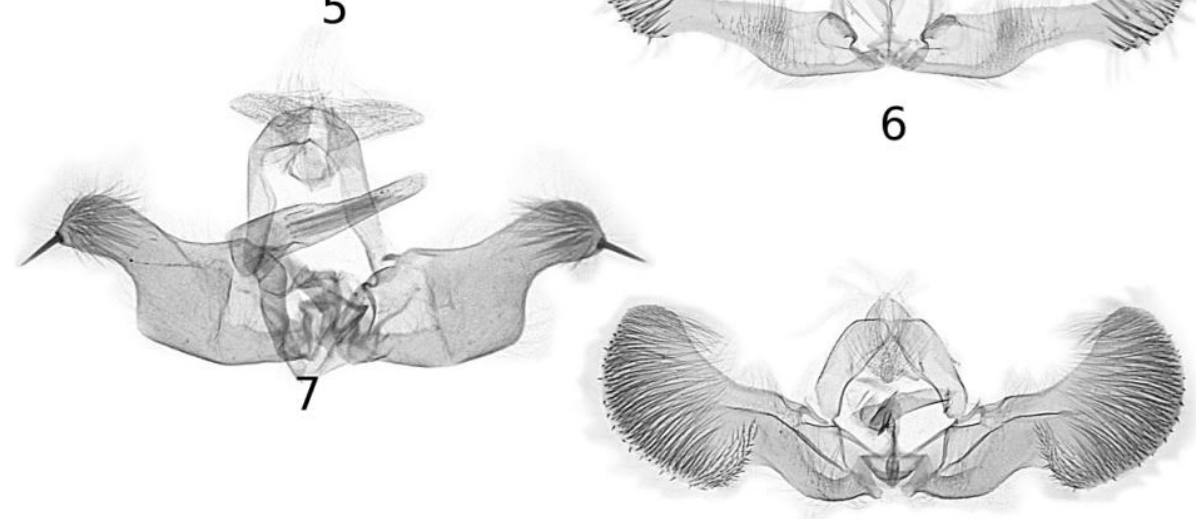

8

2

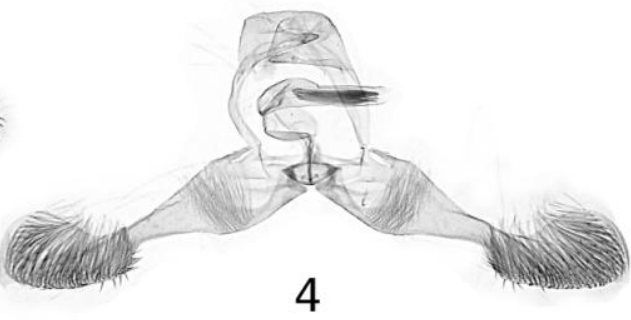

4

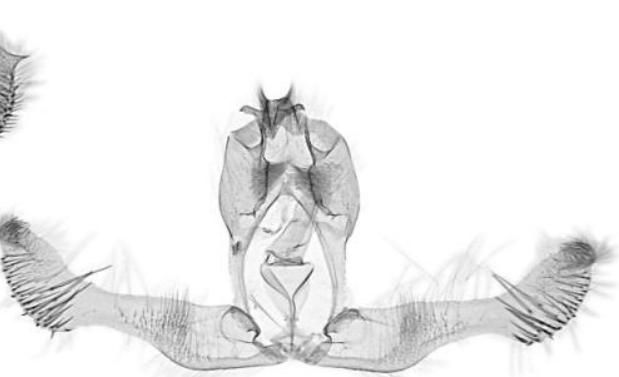

6

Figs 1-8. Male genitalia: 1 - Quebradnotia caracae sp. n., holotype, 2 - Quebradnotia maestrae sp. n., holotype, 3 - Latortona figurata sp. n., holotype, 4 - Latortona percosa sp. n., holotype, 5 - Crocidosema brunna sp. n., holotype, 6 - Chimoptesis ramulifera sp. n., holotype, 7 - Pelochrista crassocia sp. n., holotype, 8 - Eucosma leucodesma MEYRICK, 1911, Paraná, Brazil. 

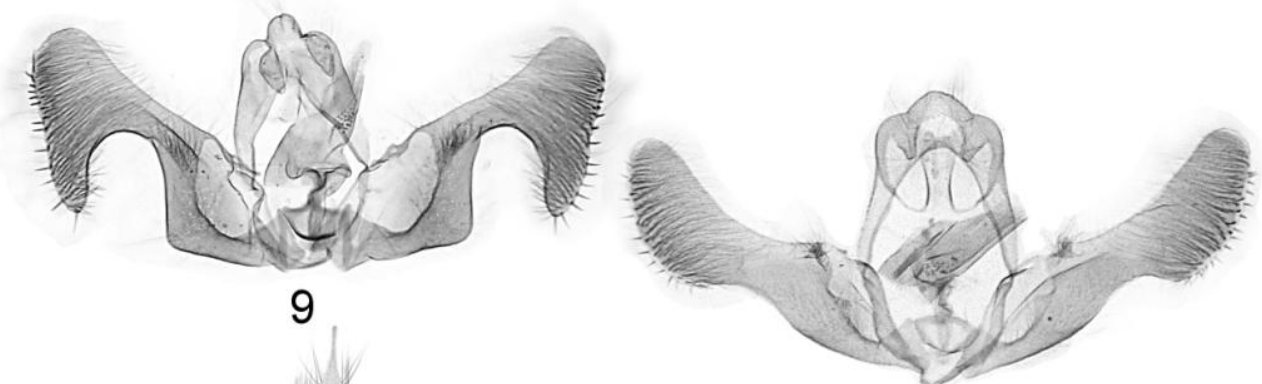

10
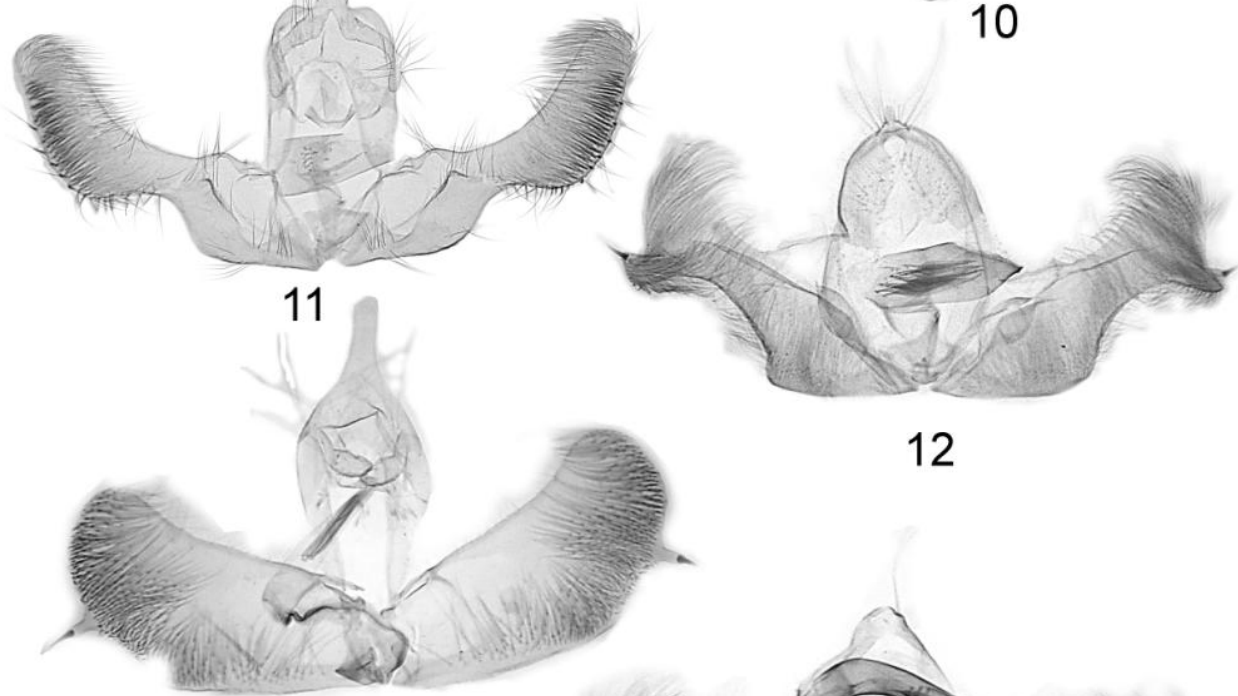

12

13

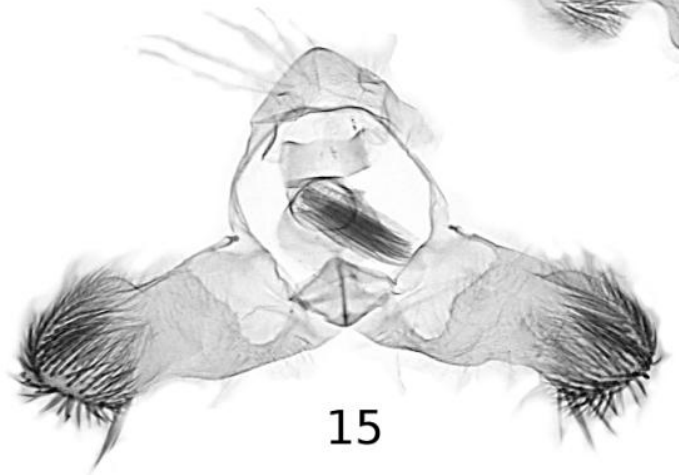

Figs 9-15. Male genitalia: 9 - Eucosma sinus sp. n., holotype, 10 - Epiblema elensino sp. n., holotype, 11 - Epiblema ayalae sp. n., holotype, 12 - Pseudexentera translucens (Walsingham, 1914), Carchi, Ecuador, 13 - Pollexinia argentigriseola sp. n., holotype, 14 - Rhyacionia lathrea sp. n., holotype, 15 - Corticivora obispo sp. n., holotype. 

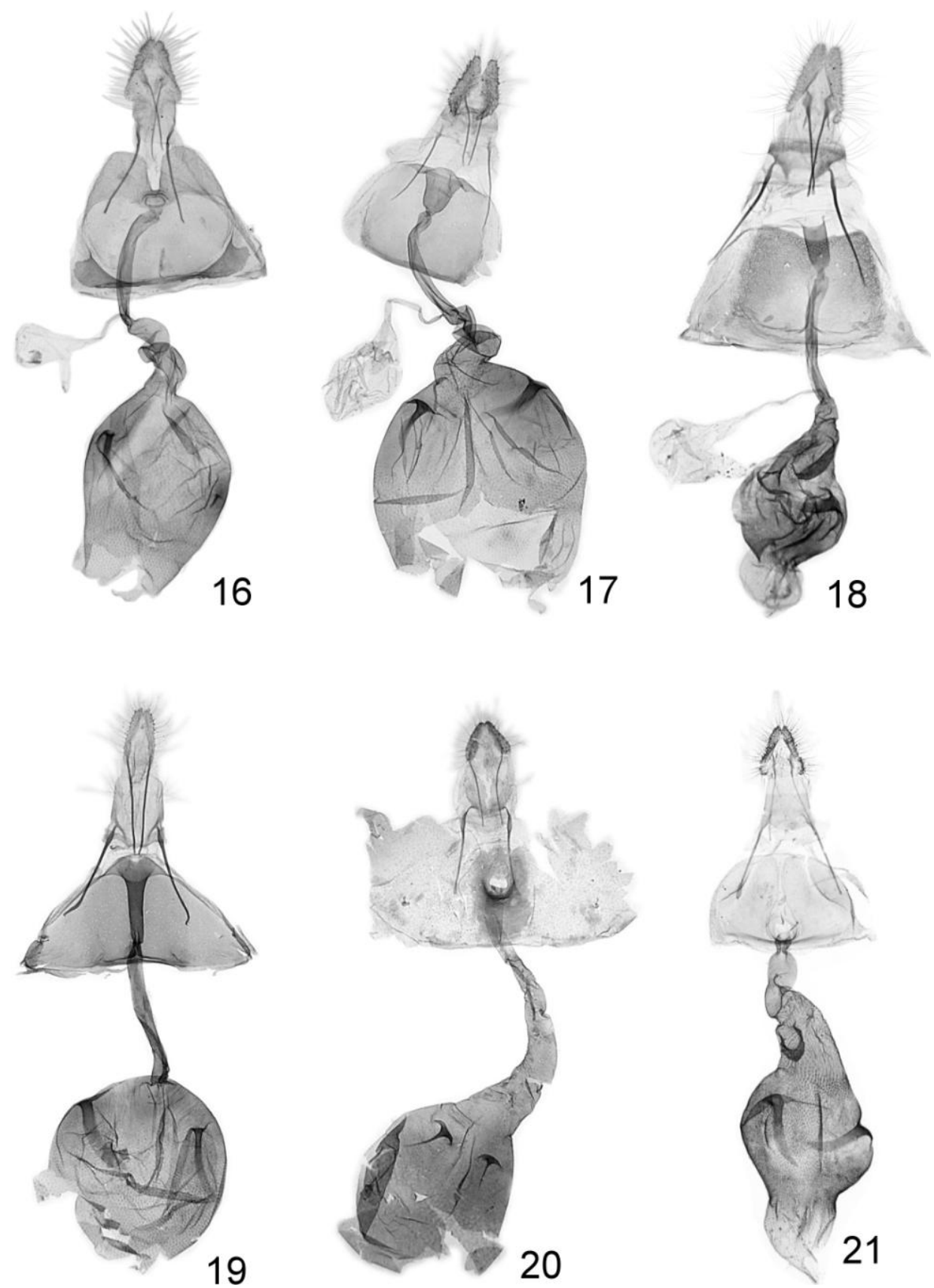

Figs 16-21. Female genitalia: 16 - Quebradnotia longiloba sp. n., holotype, 17 - Latortona guaramiranga sp. n., holotype, 18 - Crocidosema obta sp. n., holotype, 19 - Crocidosema brunna sp. n., paratype, 20 - Eucosma leucodesma MEYRICK, Mostardas, Brazil, 21 - Pseudexentera translucens (WALSINGHAM, 1914), Carchi, Ecuador. 

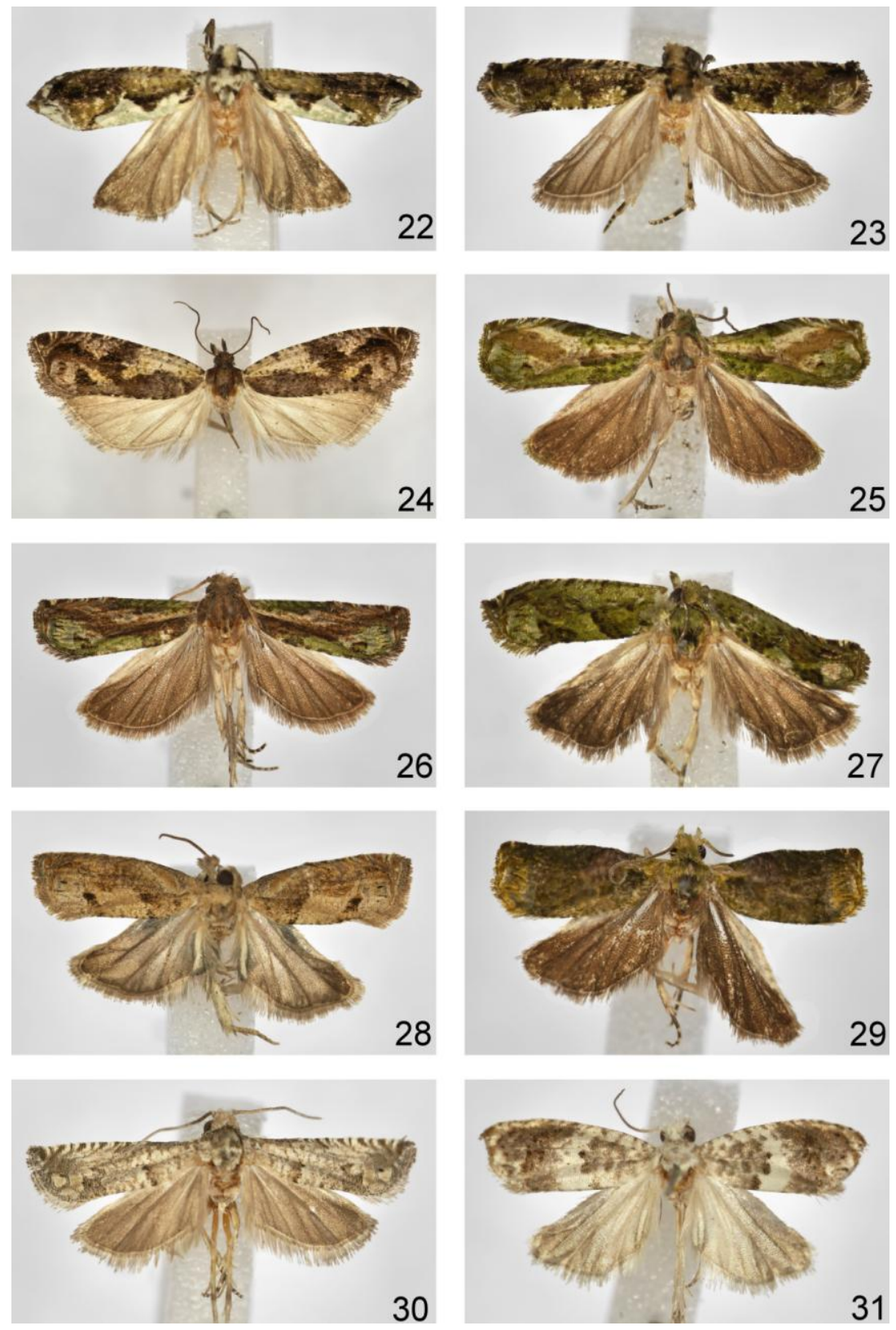

Figs 22-31. Adults: 22 - Quebradnotia caracae sp. n., holotype, 23 - Quebradnotia maestrae sp. n., holotype, 24 - Laculataria longiloba sp. n., holotype, 25 - Latortona figurata sp. n., holotype, 26 - Latortona percosa sp. n., holotype, 27 - Latortona guaramiranga sp. n., holotype, 28 - Crocidosema brunna sp. n., holotype, 29 - Chimoptesis ramulifera sp. n., holotype, 30 - Pelochrista crassocia sp. n., holotype, 31 - Eucosma leucodesma MEYRICK, 1911, Paraná, Brazil. 


\section{Type material}

Holotype male: "Brazil: M[inas]G[erais], Caraca 1300 m, 1-2. IV.1992, V.O. BECKER; Col; Col. BECKER 85273"; GS 1097 WZ.

\section{Etymology}

The name refers to the type locality, Caraca.

\section{Quebradnotia maestrae sp. n.}

(Figs 2, 23)

\section{Diagnosis}

Q. maestrae is related to Q. nolckeniana (ZELLER, 1877), Q. chasiographa RAZOWSKI $\&$ BECKER, 2006 and $Q$. caracae but is distinguished by small, grey dorsal patches, the reduced uncus, short, broad socii, and the short, weakly curved aedeagus.

\section{Description}

Wingspan ca $11 \mathrm{~mm}$. Head and thorax brownish; labial palpus whitish grey, basal half of tegula black. Forewing slender; termen concave beneath apex, distinctly convex medially. Ground colour brownish grey except the dorsal patches which are small, separate, greyish olive, dotted white along the margins. Remaining area sparsely dotted grey to middle suffused brown subdorsally, across mid-wing, and subapically. Ocelloid greyish at tornus, whiter otherwise. Cilia brownish, paler at tornus. Hindwing pale brownish, cilia similar.

Male genitalia (Fig. 2). Uncus vestigial; socius broad with short terminal part and subsquare lateral lobe; neck of valva indistinct; cucullus rounded caudally; end part of sacculus slightly convex; aedeagus moderately long, weakly bent beyond zone.

Female unknown.

\section{Type material}

Holotype male: "Cuba: S[an]t[iag]go, Sierra Maestra P. Cuba, 31. VII. 1500 m, V.O. BeCKER Col; Col. BECKER 73607"; GS 1245 WZ. Paratype male, "Cuba: Pinar Rio, Sierra Rosario 400 m, 4-6. X. 1989, V.O. BECKER Col; Col. BECKER 70687”; GS 1196 WZ.

\section{Etymology}

The specific epithet refers to the mountains of Sierra Maestra. 


\section{Laculataria longiloba sp. $\mathbf{n}$.}

(Figs 16, 24)

\section{Diagnosis}

L. longiloba is related to the Ecuadoran L. atrovirens RAZOWSKI \& BECKER, 2014 but $L$. longiloba has a broader, greenish forewing, distinctly expanding posterad, unequally size signa (one is minute while in L. atrovirens the two are almost equal in sized, broad, large), and large distal lobes of the subgenital sternite.

\section{Description}

Wingspan $21 \mathrm{~mm}$. Head, terminal third of labial palpus and thorax reddish brown. Forewing expanding terminad; costa weakly convex; termen somewhat oblique, distinctly concave in middle. Ground colour whitish indistinctly mixed brownish, spotted reddish brown, suffused pale reddish brown in distal half of wing, reddish brown in dorsal area; costal strigulae white; divisions dark brown; ocelloid greyish with three brown spots. Markings dark brown consisting of remnants of dorsobasal blotch, costal half of median fascia, tornal blotch, and a fascia extending from the latter to the apex. Cilia brownish. Hindwing brownish cream, browner on peripheries; cilia similar.

Male unknown.

Female genitalia (Fig. 24). Sterigma ill-defined; antrum sclerite very slender, short; cingulum long; proximal part of ductus bursae broad twice coiled; one signum long, slender, the other very small, slender.

\section{Material examined}

Holotype female: "Ecuador: Carchi, Maldonado 3200 m, 11. 3. 1993, V.O. BECKER Col; Col. BECKER 105421"; GS 820 WZ.

\section{Laculataria figurata sp. $\mathbf{n}$.}

(Figs 3, 25)

\section{Diagnosis}

L. figurata is related to L. rhamna RAZOWSKI \& BECKER 2017 Brazilian but differs from it chiefly in having a lobate socius, a distinct neck of the valva, and an elliptical cucullus.

\section{Description}

Wing span $14 \mathrm{~mm}$. Head and thorax cream, labial palpus marked greenish subterminally, vertex brownish; tegula with greenish posterior marks, thorax brownish posteriorly. Forewing 
broad posteriorly; costal fold to before middle; costal half of termen slightly concave. Ground colour greenish with dark green suffusions and spots; ocelloid darker; costal strigulae slender, long, white; divisions dark mostly blackish green; white fascia from wing base to $3 / 4$ of costa; pale rust brown fascia from end of median cell to beneath apex. Markings black-green in form of remnants of basal blotch and costal part of median fascia. Cilia brown. Hindwing brown, cilia paler.

Male genitalia (Fig. 3). Distal part of tegumen broad, concave apically; uncus absent; socius well sclerotized with triangular soft lobe and curved, spinose terminal half; basal part of valva large; neck short; sacculus angulate; cucullus elliptical, setose, left with two long ventrocaudal spines; aedeagus slender, produced ventroterminally.

Female unknown.

\section{Type material}

Holotype male: "Brasil: S[anta]C[atarina], Brusque 100 m, 5. I. 1989, V.O. BECKER Col; Col. BECKER 61066"; GS 692 WZ.

\section{Etymology}

The name refers to the differentiated colouration of the adult; Latin: figurata - formed.

\section{Laculataria percosa $\mathbf{s p .} \mathbf{n}$.}

(Figs 4, 26)

\section{Diagnosis}

L. percosa is related to L. diplocosma RAZOWSKI \& BECKER 2017b from Santa Catarina, Brazil but differs from it in having an elongate cucullus with a prominence of the caudal edge (in L. diplocosma the cucullus is subtriangular with a simple caudal edge).

\section{Description}

Wingspan $14.5 \mathrm{~mm}$. Head and thorax rust brown, labial palpus whitish with brown marks. Forewing weakly expanding posteriorly; costal fold slender, reaching mid-costa; termen straight to middle. Dorsum from middle to tornus white suffused green; costal strigulae white, fine; divisions rust brown; costal fold dark green strigulated black; radial fascia from wing base to end of median cell whitish marked brown, followed by whitish brown strip towards apex; inner strigulae of ocelloid and some tornal dots black; dorsal half of wing from base to end of median cell rust brown. Cilia brownish with rust brown parts. Hindwing brown, cilia paler.

Male genitalia (Fig. 4). Distal edge of tegumen broad, almost straight; socius elongate, wedge-shaped; basal part of valva broad; neck long, tapering posteriorly; sacculus angulate; 
cucullus elongate, broad posteriorly with caudal hairless prominence postmedially; aedeagus simple, moderately broad; cornuti long.

Female unknown.

\section{Type material}

Holotype male: "Brasil: R[io de]J[aneiro], Nova Friburgo 800 m, 22. I. 1993, V.O. BECKER Col; Col. BeCKER 86037", GS 691 WZ. Paratype male: "Brasil: R[io de]J[aneiro], Nova Friburgo 300 m, 22. I. 1993, V.O. BECKER Col; Col. BECKER 36037", GS 693 WZ.

\section{Etymology}

The specific name refers to the colouration of the adult: Greek: perkos - dark.

\section{Remarks}

L. percosa is included in Latortona on the basis of the lack of an uncus and the shapes of the socii and aedeagus. As the cucullus has a prominence of the caudal edge it resembles $L$. Iatitaia (both these genera were described by RAZOWSKI \& BECKER (2017 b).

\section{Latortona guaramiranga sp. $\mathbf{n}$.}

(Figs 17, 27)

\section{Diagnosis}

$L$. guaramiranga is closely related to $L$. diplocosmea RAZOWSKI \& BECKER (2017b) from Santa Catarina, Brazil but $L$. guaramiranga has a greenish forewing ground colour, small postostial sterigma, a shorter, expanding posterad cup-shaped part of sterigma, long, slender terminations of the signa, and a short subgenital sternite.

\section{Diagnosis}

Wingspan $16 \mathrm{~mm}$. Head and thorax greenish. Forewing slightly expanding terminad; costa straight to $2 / 3$; termen weakly sinuate. Ground colour greenish, mixed white dorsally between markings and along edges of tornal blotch; costal strigulae whitish and whitish green; divisions blackish; ocelloid whitish grey. Markings consist of dorsobasal blotch and tornal blotch, the former blackish posteriorly. Cilia brownish. Hindwing brown, cilia paler.

Male unknown.

Female genitalia (Fig. 17). Eighth tergite short; postostial sterigma strongly convex posteriorly; cup-shaped part of sterigma expanding posterad; cingulum long, slender; proximal part of ductus bursae coiled twice; signa with long, thread-like terminations. 


\section{Material examined}

Holotype female: "Brasil: CE[ará], Guaramiranga 1000 m, 9. IV. 1994, V.O. BECKER Col; Col. BECKER 92172”; GS 1123 WZ.

\section{Etymology}

The specific name refers to the type locality, Guaramiranga.

\section{Gretchena argentigriseola sp. n.}

(Figs 12, 37)

\section{Diagnosis}

G. argentigriseola is most closely related to the Ecuadoran G. garai MILLER, 1987 but differs from it in that the forewing ground colour is silver, an uncus is present and the ventroterminal lobe of the cucullus is hairy.

\section{Description}

Wingspan $14 \mathrm{~mm}$. Head whitish brown, brown between bases of antennae; labial palpus and distal half of tegula white; proximal half of thorax brownish, basal half of tegula dark brown. Forewing mostly slender, somewhat broadening postbasally; costa gradually convex; termen slightly convex, not oblique. Ground colour white; suffusions yellowish brown, spots pale brown; costal strigulae white, indistinct; divisions brown. Markings brown consisting of postbasal blotch at costa, postmedian costal suffusion, and some spots in postmedian area of wing; dorsum strigulated grey to middle. Cilia (remnants) whitish with brown interruptions mostly at apex. Hindwing creamish suffused brown beyond middle, brown on peripheries; cilia whitish.

Male genitalia (Fig. 12). Uncus small, well sclerotized; socius large, ovoid; basal half of valva broad with broad, fairly long neck; sacculus angulate; ventral process of cucullus large with pollex; aedeagus broad, extending ventroposteriorly; cornuti numerous, broad submedially.

Female unknown.

\section{Type material}

Holotype male: "Ecuador: Carchi, Maldonado 2200 m, 9. II. 1993, V.O. BECKER Col; Col. BECKER 105320”; GS 1280 WZ. 

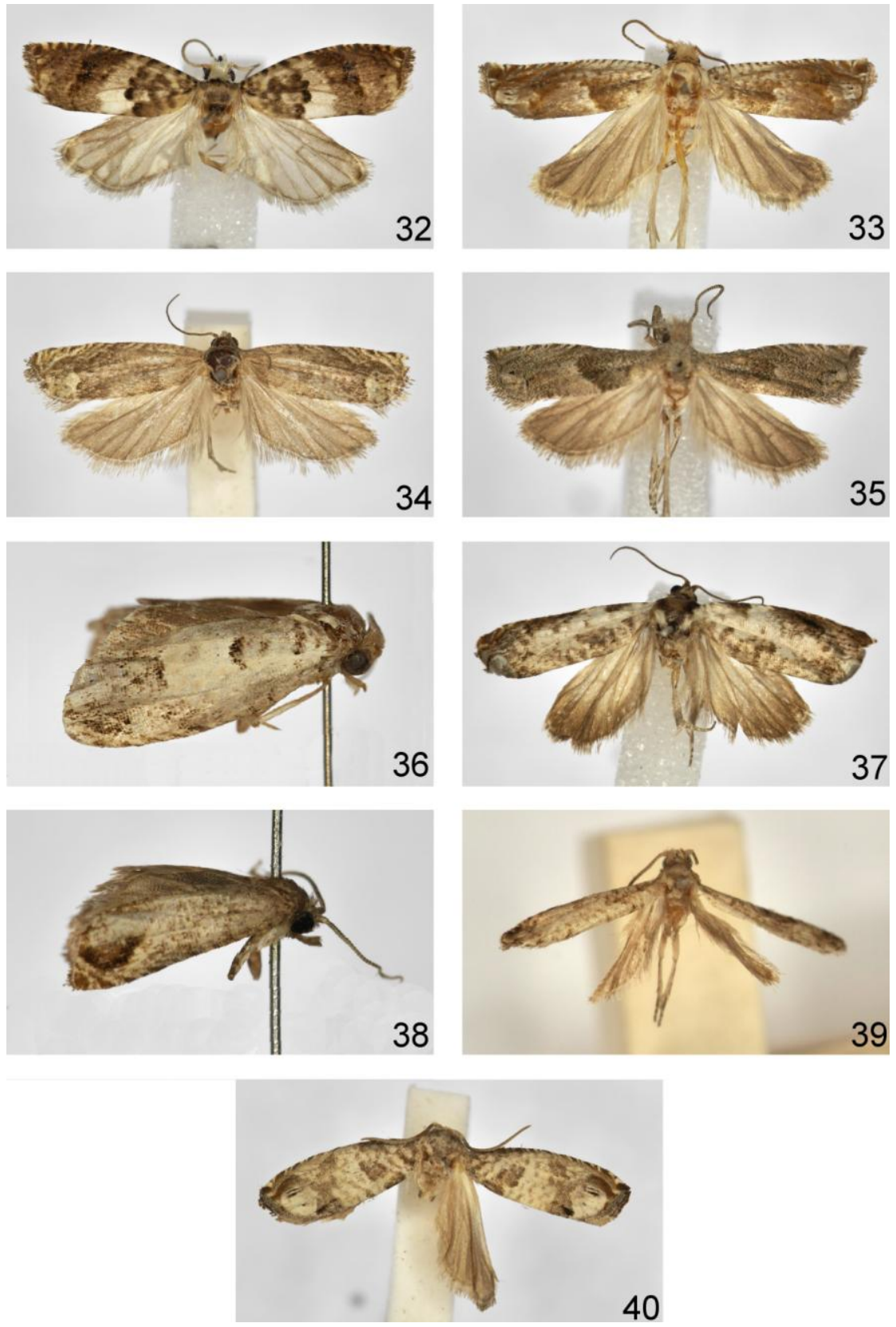

Figs 32-40. Adults: 32 - Eucosma leucodesma MEYRICK, Paraná, Brazil, GS 942 WZ, 33 - Eucosma ? leucodesma MEYRICK, 1911, Mostardas, Brazil, GS 1051 WZ, 34 - Eucosma sinus sp. n., holotype, 35 - Epiblema elensino sp. n., holotype, 36 - Epiblema ayalae sp. n., holotype, 37 - Gretchena argentigriseola sp. n., holotype, 38 - Pollexinia costaricae sp. n., holotype, 39 - Rhyacionia lathrea sp. n., holotype, 40 - Corticivora obispo sp. n., holotype. 


\section{Etymology}

The name refers to the colouration of the forewing; Latin - argenteus - silvery, griseola greyish.

\section{Rhyacionia bushnelli (BUSCK, 1914)}

\section{Material examined}

One male: "Rhyacionia frustrana (COMSTOCK, 1880) [det. R. SALAZAR] Costa Rica: Cartago, Turrialba 600 m, 27. X. 1981, R. SALAZAR col., ex larvae Pinus caribaea"; VOBC 39567; GS 1009 WZ.

\section{Rhyacionia cibriani (MILLER, 1988)}

\section{Material examined}

Six males from Veracruz, Mexico: Cofre de Parote 3300 m, 4. VI. 1997; VOBC 109499; GS 1365 WZ.

\section{Remarks}

R. cibriani was described from Paso del Cortez, Federal District, Mexico; they were collected in mid-April and the altitude was not mentioned. Our specimens were collected in June at an altitude of $3300 \mathrm{~m}$.

\section{Rhyacionia lathrea sp. $\mathbf{n}$.}

(Figs 14, 39)

\section{Diagnosis}

In the male genitalia, $R$. lathrea resembles the Nearctic $R$. pasadenana (KEARFOTT, 1907) but $R$. lathrea differs from it chiefly in its long, slender aedeagus. $R$. lathrea is closely related to the Palaearctic $R$. pinicolana (DOUBLEDAY, 1850) from which it differs distinctly in the facies; $R$. pinicolana is larger (wingspan 17-24 mm) and the forewings have an orange colouration. $R$. lathrea differs from pinicolana chiefly in the deep ventral incision of the valva, the larger ventral lobe of the cucullus, and the ventroterminal process of the aedeagus.

\section{Description}

Wingspan $9 \mathrm{~mm}$. Head and thorax whitish, labial palpus brownish laterally. Forewing not expanding terminad; costa almost straight; termen moderately oblique, straight. Ground colour 
whitish sprinkled pale brownish, parallel pale brown strigulations; costal strigulae whitish; divisions brownish, subapical ones dark brown. Markings in form of yellowish brown, dark brown edged triangular costal blotch. Cilia (worn) pale brownish. Hindwing brownish grey.

Male genitalia (Fig. 14). Tegumen tapering posteriorly; socii minute; valva broad; ventral incision deep; sacculus large, straight ventrally, angulate; cucullus subsquare; aedeagus long with large ventroposterior process; cornuti moderately long.

Female unknown.

\section{Type material}

Holotype male: "Turrialba, Costa Rica, Turrialba 600 m, XI. 1971; VOBC 36029”; GS 990 WZ.

\section{Etymology}

The name refers to the small characters differentiating the genitalia; Greek: lathrea secretly.

\section{Crocidosema obta RAZOWSKI \& BECKER, 2014}

(Fig. 18)

\section{Description}

Female genitalia (Fig. 18). Eighth tergite short; apophyses fairly long; sterigma submembranous; antrum fairly broad, moderately long; sclerite (cingulum) of ductus bursae very long; signa unequally large; proximal part of corpus bursae bulbous. Proximal sclerite of subgenital sternite reduced to a transverse fold.

\section{Material examined}

One female from the Province of Sucumbios, Ecuador (Santa Barbara 3400 m, 8. I. 1993 , VOBC 104338; GS 979 WZ).

\section{Remarks}

C. obta was described from the Province of Loja, Ecuador, from an altitude of $2700 \mathrm{~m}$. 


\section{Crocidosema brunna sp. n.}

(Figs 5, 19, 28)

\section{Diagnosis}

C. brunna is related to the Colombian $C$. dolicha RAZOWSKI \& WOJTUSIAK, 2011, comb. n. but $C$. brunna is distinguished by the two dark brown dorsal marks on the forewing, the ovoid cucullus and the long, slender aedeagus.

\section{Description}

Wingspan $16 \mathrm{~mm}$. Head and thorax pale brownish. Forewing slightly expanding terminad; termen somewhat concave beneath apex. Ground colour brownish; dorsal patch poorly defined, cream brown; costal strigulae brownish cream; divisions pale brown; ocelloid pale brown, dorsally fused with dorsal patch, with dark brown inner spots. Basal third of wing slightly darker than dorsal patch, posterior half of costal fold yellowish brown, basal part brownish. Markings ill-defined: median fascia atrophying dorsally; two dark brown dorsal spots, one being a remnant of basal blotch, the other tornal. Cilia brownish, darker at apex. Hindwing brownish; cilia brownish cream.

Variation. Female darker than male with distinct dorsal marks.

Male genitalia (Fig. 5). Uncus large, helmet-shaped, weakly sclerotized; socius dorsolateral; valva broad to beyond middle; neck slender; sacculus rounded ventrocaudally; cucullus ovoid with broad ventral lobe and submedian, sharp process from caudal edge; aedeagus long, slender; cornuti 2.5 times shorter than aedeagus.

Female genitalia (Fig. 28). Ovipositor fairly long, apophyses long; sterigma rather small, concave distally; sclerite of antrum long; almost entire ductus bursae well sclerotized; signa equally large, long.

\section{Type material}

Holotype male: "Brasil: S[anta]C[atarina], São Joaquim 1400 m, 25. X. 1995, V.O. BECKER Col; Col. BECKER 98174”; GS 1133 WZ. Paratypes, identically labelled male and female, the latter with GS $1132 \mathrm{WZ}$.

\section{Remarks}

In the diagnosis, this species was compared to $C$. dolicha, which was described in Pseudexentera HEINRICH, 1940. Two other undescribed species with variably developed uncus and cucullus form a small group within Crocidosema ZELLER. 


\section{Chimoptesis setoses RAZOWSKI \& BECKER, 2015}

\section{Material examined}

One male from Cuba (Santiago, Turuino 470 m, 27-29. VII. 1990; VOBC 73395, GS 1179 WZ).

\section{Remarks}

C. setoses was described from Gran Piedra (Santiago, Cuba) from an altitude of $400 \mathrm{~m}$.

\section{Chimoptesis ramulifera sp. $\mathbf{n}$.}

(Figs 6, 29)

\section{Diagnosis}

C. ramulifera most resembles C. cornigera RAZOWSKI \& BECKER, 2015 from Mexico: the uncus bears processes, and it has the broad, lateral socii which occur in many other Chimoptesis species; C. ramulifera differs noticeably from all other Chimoptesis in the forewing shape and pattern and in the peculiar slender valvae.

\section{Description}

Wingspan $12 \mathrm{~mm}$. Head cream tinged olive brown, labial palpus cream white; thorax olive brown with darker marks. Forewing not expanding terminad; costa slightly depressed postmedially with fold to beyond $1 / 3$; termen sinuate beneath apex. Ground colour brownish cream in form of multiple diffuse spots among brown suffusion; costal strigulae very small, white; divisions dark brown, indistinct; ocelloid orange cream with brown inner spots. Markings ill-defined, dark brown, retained in basal and median parts of wing. Cilia concolorous with ocelloid. Hindwing and cilia brown.

Male genitalia (Fig. 6). Uncus short, densely hairy, with a pair of well sclerotized processes; socius very broad, laterally armoured with dorsal process and dense tuft of terminal hairs; valva slender; neck long; ventral incision long, shallow; sacculus weakly angulate; cucullus elongate-ovate with some long spines; aedeagus short; olethreutoid fairly long.

Female unknown.

\section{Type material}

Holotype male: "Brasil: S[ão]P[aulo], S[ão] Paulo 1000 m, 29. I. 1993, V.O. BECKER Col; Col. BECKER 86837”; GS 1120 WZ. 


\section{Etymology}

The specific name refers to the shape of the uncus; Latin - ramulus - a small branch and fero - I carry.

\section{Pelochrista crassocia sp. $\mathbf{n}$.}

(Figs 7, 29)

\section{Diagnosis}

$P$. crassocia is related and similar to the Nearctic $P$. zomonana (KEARFOTT, 1907) but crossocia has a whitish head, thorax and forewing ground colour and the caudal part of the cucullus is rounded.

\section{Description}

Wingspan $13 \mathrm{~mm}$. Head and thorax whitish, labial pulpi brownish along middle of median joint, thorax spotted grey. Forewing expanding slightly terminad; costa almost straight with fold to beyond 1/3; termen straight, weakly oblique. Ground colour white suffused and strigulated grey; costal strigulae white; divisions, costal fold and suffusions grey; markings grey, dorsobasal markings blackish posteriorly; ocelloid whitish. Cilia pale grey, whiter towards tornus. Hindwing brownish; cilia whitish grey.

Male genitalia (Fig. 6). Uncus small; socius large, broad, tapering terminad; gnathos weak; valva broad to $2 / 3$, sacculus weakly convex, angulate; neck short; cucullus rounded posteriorly; pollex subventral; aedeagus almost as long as costa of valva; cornuti long.

Female not known.

\section{Type material}

Holotype male: "Mexico: Tam[aulipas] 250 m, 4-13. VIII. 1988, V.O. BECKER Col; Col. BECKER 69140"; GS 1339 WZ. The paratypes are two identically labelled males.

\section{Etymology}

The name refers to the shape of the socius; Latin: coryssus - thick. 


\section{Eucosma leucodesma MEYRICK, 1911}

(Figs 8, 20, 31, 32)

\section{Diagnosis}

In facies, E. leucodesma resembles the Nearctic Eucosma parmatana (CLEMENS, 1860) but in the latter the ventral incision of the valva is deep and the postostial sterigma is slender.

\section{Description}

Wingspan $14 \mathrm{~mm}$. Head and thorax white, latter with brownish marks. Forewing slightly expanding posteriorly; costa weakly convex; termen somewhat concave beneath apex. Ground colour white very slightly tinged brownish in costal area to median fascia, pale brownish beyond latter, brown towards apex. Ocelloid area white posteriorly with two black dots; costal strigulae whitish, small; divisions brown. Basal blotch consisting of numerous brownish spots, some of which dark brown posteriorly; median fascia pale brownish with two blackish spots medioposteriorly. Cilia brownish, whiter at tornus. Hindwing whitish tinged pale brown, darker posteriorly; cilia white.

Variation. Female similar to male but with white forewing ground colour areas and paler, greyer markings. One male smaller, pale with wing span $12 \mathrm{~mm}$.

Male genitalia (Fig. 8), hitherto unknown. Uncus broad with minute apical projection; socius large; neck of valva broad, ventral incision moderate; sacculus short, convex; cucullus broad, convexly rounded caudally with broad ventral lobe from which a row of spines extends dorsally; aedeagus small, shorter than sacculus, moderately broad.

Female genitalia (Fig. 20). Eighth tergite weakly sclerotized, not emarginate ventrolaterally; apophyses slender; postostial sterigma fused with posterior parts of subgenital sternite; ostium large; antrum weakly sclerotized, fairly long; cingulum absent; blades of signa slender. Subgenital sclerite well sclerotized along middle, strongly so ventrally to ostium bursae, weakly laterally.

\section{Material examined}

Three males and two females: "Brasil: P[a]R[aná], Telemaco Borba 750 m, 13-19. X. 1995, V.O. BECKER Col; Col. BECKER 97800"; GS 942 WZ. One male from Rio Brilhante, Mato Grosso, 25. I. 1971, VOBC 13768, GS 1336 WZ has similar genitalia but different facies. Two specimens from Rio Grande do Sul (Mostardas 5 m, 13. I. 1989; GS 1051 WZ, 1052 WZ) differ externally from the others.

\section{Remarks}

Two specimens from Rio Grande do Sul (Mostardas 5 m, 13. I. 1989; GS 1051 WZ, 1052 WZ) have a brownish cream head and thorax, a slenderer forewing, brownish markings, and 
a pale brown hindwing. The differences in the genitalia are, however, slight: in the males the uncus is triangular and the dorsal part of the cucullus is elongate; in the females the median sclerotization of the subgenital sternite is weak. These (Fig. 33) specimens may represent a distinct species or subspecies.

\section{Eucosma sinus sp. $\mathbf{n}$.}

(Figs 9, 34)

\section{Diagnosis}

E. sinus is similar and closely related to E. vogelana WRIGHT, 2010 from Colorado, USA, but differs from it in having a broader neck of the valva, a concave caudal edge of the cucullus, and a broad, short aedeagus.

\section{Description}

Wingspan $15 \mathrm{~mm}$. Head and thorax cream brown. Forewing almost uniformly broad; costa straight; termen slightly oblique, fairly straight. Ground colour pale cream brown; costal strigulae and ocelloid cream white; divisions pale brownish. Trace of dorsal patch cream brown. Cilia brownish, creamer at tornus. Hindwing brownish cream, browner on peripheries; cilia cream.

Variation. Paratype forewing more brownish grey than described above; dorsal patch creamish.

Male genitalia (Fig. 9). Uncus helmet-shaped; socius constricted basally; valva broad to middle; neck moderate; dorsal lobe of cucullus broad, short; ventral lobe long, tapering ventrally; caudal edge of cucullus slightly concave; sacculus angulate; aedeagus broad to middle.

Female not known.

\section{Type material}

Holotype male: "Mexico: D[istrito]F[ederal], Mexico 2600 m, 24. VII. 1981, V.O. BECKER Col; Col. BECKER 41855"; GS 1012 WZ. The paratypes are two identically labelled males.

\section{Etymology}

The specific name refers to the ventral incision of the valva; Latin: sinus - bay. 


\section{Epiblema elensino sp. $\mathbf{n}$.}

(Figs 10, 35)

\section{Diagnosis}

E. elensino is externally similar and related to the Nearctic E. luctuosissima BLANCHARD, 1985 but differs from it chiefly in having a large ventral incision in the valva, an apically tapering cucullus, and a subtriangular socius.

\section{Description}

Wingspan $6.5 \mathrm{~mm}$. Head brownish cream, frons white; thorax grey. Forewing costa straight, fold to before middle; termen sinuate beneath apex, not oblique. Ground colour cream grey preserved in costal part of dorsal patch and ocelloid; costal strigulae greyish except for two subapical white ones; basal half of wing dark grey with convexly rounded posterior edge, dark blackish grey, sprinkled white and blackish; posterior area pale grey densely sprinkled white. Cilia concolorous with latter, whiter at tornus. Hindwing pale brownish, paler basally; cilia whitish.

Male genitalia (Fig. 10). Uncus broad, short; socius tapering terminad; posterior edge of basal cavity of valva with submedian extension, horn large; neck of valva fairly broad; ventral incision long, shallow; cucullus tapering posteriorly with small ventral lobe and weakly convex caudal edge; aedeagus broad.

Female not known.

\section{Type material}

Holotype male: "Mexico: Tam[aulipas] 250 m, 4-13. VIII. 1988, V.O. BECKER Col; Col. BECKER 69141"; GS $1320 \mathrm{WZ}$.

\section{Etymology}

The specific epithet refers to the type locality, El Ensino.

\section{Epiblema ayalae sp. $\mathbf{n}$.}

(Figs 11, 36)

\section{Diagnosis}

E. ayalae is related to the Nearctic E. desertana (ZeLLER, 1875) but the distinguishing characters of ayalae are the white colouration of the forewings, the long, slender uncus, the long socius and the elongate cucullus. In desertana the base of the forewing is blackish, the socius is short, and the cucullus is broad and oval. 


\section{Description}

Wingspan $12.5 \mathrm{~mm}$. Head brownish cream; thorax whitish (worn). Forewing not expanding terminad; costa slightly convex; termen not oblique. Ground colour white with a few pale brownish marks along dorsum; divisions pale brown. Markings in form of remnants of brown spots at base dorsally, submedially and at tornus; brown marking subapically. Cilia damaged. Hindwing brownish.

Male genitalia (Fig. 11). Uncus long, broad basally; socius long; basal part of valva broad; horn minute, situated on subtriangular fold; neck of valva short; ventral incision rounded; cucullus elongate, tapering apicad; aedeagus short, broad.

\section{Type material}

Holotype male: "Mexico: Gro., Villa Ayala, 25. VI. 1971, V.O. BECKER Col; Col. BECKER 39210"; GS WZ 981 WZ.

\section{Etymology}

The name refers to the type locality, Villa Ayala.

\section{Pseudexentera translucens (WALSINGHAM, 1914), comb. n.}

(Fig. 21)

\section{Material examined}

Holotype female: "Amula $6000 \mathrm{ft}$ Guerrero, Mexico VIII. [19]13[?] (H.H. SMITH) G[O]DM.[AN]S[A]LV[I]N. 66437”; 5574 T[ype] BM(NH).

One female from Ecuador, Carchi, Maldonado 2200 m, 9-11. I. 1993, VOBC 205316; GS $1304 \mathrm{WZ}$.

\section{Description}

Female genitalia of a specimen from Ecuador (Fig. 21). Ovipositor fairly short; sterigma fused with subgenital sternite, slightly convex posteriorly, slender in distal half; anteostial part of sterigma very slender; antrum membranous; ductus bursae broad with postbasal sac; cingulum weakly sclerotized, median; proximal part of corpus bursae elongate; signa two large blades, almost equal in size. Subgenital sternite rounded posteriorly with lateroposterior folds and simple, sclerotized anterior edge. 


\section{Proteoteras atromacula RAZOWSKI \& LANDRY, 2008}

\section{Material examined}

Ten males from British Virgin Islands (Mt. Sage N.P., 460 m, 13-15. VII. 1987, VOBC 66923; GS 1307), Puerto Rico (Patillas 590 m VIII. 1987, VOBC 68276; GS 1308 WZ), Tamaulipas, Mexico (El Ensino 250 m, 4-13. VIII. 1988, VOBC 69143; GS 1309 WZ).

\section{Distribution}

$P$. atromacula is widely distributed from Mexico and the Caribbean Islands to the Galapagos and Ecuador.

\section{Remarks}

$P$. atromacula was described from the Galapagos Islands. The moth shown in Figure 72 in RAZOWSKI et al. (2008) is incorrectly named: in fact, it is a Crocidosema species. The female genitalia of the Galapagos specimen do not differ from those of the Brazilian C. connexa RAZOWSKI \& BECKER (2014). One female of Crocidosema is from Mato Grosso, Brazil (Chapada do Guimaraes 800 m, 26. X. 1993, VOBC 89345; GS 1097 WZ).

One female of Proteoteras from Ecuador (Carchi, Maldonado 2200 m, 9-11. I. 1993; VOBC 105319; GS 1122 WZ) is probably conspecific with the above males. Female genitalia: posterior part of postostial sterigma slender; cingulum long, tapering posterad; one signum fairly large, the other very small; posterior lobes of subgenital sternite rounded, with broad folds.

\section{Pollexinia gen. n.}

Type species: Pollexinia costaricae sp. n.

\section{Diagnosis}

Pollexinia is a monotypic genus represented by small species, externally similar to some small Rhyacionia HÜBNER [1825] 1816. The male genitalia of Pollexinia are distinguished by a large, well sclerotized uncus and large socii as well as a subventral pollex with a strong apical spine.

\section{Description}

Venation not examined. 
Male genitalia. Uncus long, uniformly broad throughout; socius large, drooping; gnathos and subscaphium weak; valva broad with indistinct ventral incision and long, slender basal process; cucullus short, armoured with large pollex; aedeagus simple, slender; cornuti long.

Female not known.

\section{Biology and distribution}

Pollexinia is known from Turrialba, Costa Rica. The moth was collected in August at an altitude of $600 \mathrm{~m}$.

\section{Etymology}

The name refers to the pollex in the male genitalia.

\section{Pollexinia costaricae sp. n.}

(Figs 13, 38)

\section{Diagnosis}

In the facies, $P$. costaricae somewhat resembles the Nearctic Rhyacionia rigidana (FERNALD, 1880) but has a pale brownish forewing ground colour and a distinct subapical brown blotch.

\section{Description}

Wingspan $8.3 \mathrm{~mm}$. Head and thorax pale brownish. Forewing weakly expanding posteriorly; costa straight; termen moderately oblique, straight. Ground colour brownish cream strigulated pale brown; costal strigulae weak, more cream; divisions brown, posterior ones and apex rust. Markings reduced to subapical rust brown blotch extending from median cell to termen, edged brown costally. Cilia brownish. Hindwing pale brown, cilia similar.

Male genitalia (Fig. 13) as described for the genus.

\section{Type material}

Holotype male: "Costa Rica: Turrialba 600 m, VIII. 1971, V.O. BECKER Col; Col. BECKER 37044”; GS WZ 983 WZ. Paratype male, similar label but date VI. 1972, VOBC 36729, GS $984 \mathrm{WZ}$.

\section{Etymology}

The name refers to the country of origin. 


\section{Corticivora obispo sp. n.}

(Figs 15, 40)

\section{Diagnosis}

The male genitalia of $R$. obispo resemble those of the Palaearctic $R$. piniana (HERRICHSCHÄFFER, 1861) but have a broad valva and a short aedeagus. The colouration of the forewings is whitish.

\section{Description}

Wingspan $13 \mathrm{~mm}$. Head greyish, labial palps brownish grey laterally; thorax whitish marked grey. Forewing weakly expanding terminally; costa slightly convex; termen somewhat oblique. Ground colour white strigulated pale brownish grey, with some browner transverse lines; costal strigulae white; divisions brown. Markings brown-grey: basal blotch consisting of strigulae and incomplete fasciae, posteriorly limited by broad blotches; median fascia paler; brown streak along last radial vein towards apex. Cilia brownish. Hindwing brownish grey; cilia paler.

Male genitalia (Fig. 15). Terminal part of tegumen subtriangular; socius small; gnathos fairly well preserved; valva broad, ventral incision shallow; sacculus weakly convex; cucullus semiovate with four to five long marginal spines from ventral lobe and numerous smaller spines along caudal edge; aedeagus broad; cornuti long.

Female unknown.

\section{Type material}

Holotype male: "Mexico; Guerrero, Aguas de Obispo, 21-22. X. 1973, V.O. BECKER Col; Col. BECKER 39362"; GS 999 WZ.

\section{REFERENCES}

RAZOWSKI J., BeCKER V.O. 2014. Systematics and faunistics of Neotropical Eucosmini, 2: Epinotia HüBner, Catastega Clemens, and Crocidosema ZELler (Lepidoptera: Tortricidae). Polish Journal of Entomology 83(1): 23-59.

RAZOWSKI J., BECKER V.O. 2015a. Systematics and faunistics of Neotropical Eucosmini. Chimoptesis PowELL, 1964 (Lepidoptera: Tortricidae). Zootaxa, 3941(2): 204-220.

RAzOwski J., BecKer V.O. 2015b. Mesochariodes RAZOwsKi \& WoJTUsiaK, 2006, a Neotropical Eucosmini genus, with description of a new species (Lepidoptera: Tortricidae). Polish Journal of Entomology 84(3): 137-144.

RAZOWSKI J., BeCKeR V.O. 2017a. Systematics and Faunistics of Neotropical Eucosmini, 4: three new genera and their species (Lepidoptera: Tortricidae). Polish Journal of Entomology 86(1): 69-77. 
RAZOwski J., BeCKeR V.O. 2017b. Systematics and Faunistics of Neotropical Eucosmini, 3: Epinotiagroup of genera (Lepidoptera: Tortricidae). Polish Journal of Entomology 86(4): 303-345.

Received: 17 May 2017

Accepted: 26 August 2017 